DOI https://doi.org/10.18551/rjoas.2018-06.53

\title{
STUDY OF POLICY IMPACT ON THE INDONESIAN FRESH TUNA EXPORT: AN ECONOMETRIC APPROACH
}

\author{
Laily Dona W.*, Syafrial, Hanani N., Muslich M.M. \\ Faculty of Agricultiral, University of Brawijaya, Indonesia \\ *E-mail: donalaily29@gmail.com
}

\begin{abstract}
This study analyzes the impact of government policies to increase Indonesia's tuna exports in the international market. This study uses time series data 2000-2016. The econometric model used in this study was a simultaneous equation by including government policy variables. Analysis of the impact of Indonesia's fresh tuna trade policy on domestic and international markets were done with ex ante simulation and historical simulation using time series data 2000-2016. Results of analysis can be abstracted as follows: the policy of increasing the number of trips 25 percent impacts on the increase of tuna production by three percent; the depreciation of the rupiah exchange rate by 30 percent has an impact on the increase of fresh tuna exports to Japan by 13 percent; decrease the price of domestic fresh tuna by 10 percent resulted in an increase in domestic fresh tuna demand by 3.42 percent; decrease the interest rate of 2.5 percent could induce increasing the fresh tuna production by 13.99 percent; removal of the import tariffs could increase export of fresh tuna; use of appropriate technology could increase fresh tuna production. The production and export of Indonesian tunas were also influenced by the policies of the Indonesian government and policies of the importing countries.
\end{abstract}

\section{KEY WORDS}

Export, policies, fresh tunas fisheries, international market.

Fishery is one of the important sectors for the livelihood of the people and is one of Indonesia's core competences which have 17,504 islands (KKP, 2010; KKP, 2014a). This fishery sector becomes the prime mover of the national economy (Parris,; Sunoko and Huang, 2014). Tuna is one of the leading commodities in the program of industrialization of fisheries in Indonesia (Kusumastanto, 2008; KKP, 2011). This is because tuna is a type of fish with high economic value and is the second foreign exchange earning commodity after shrimps (Onolawe and Fitri, 2011). In 2011, tuna commodities contributed US $\$ 498,591,000$ or 14 percent of the total value of Indonesian fishery exports. During the period of 20092011, the potential of tuna production in Indonesia reached 1.2 million tons per year, with export value of more than 3.5 billion US Dollars (Spare and Venema, 1999; Reid et al., 2003; Sularso, 2009; Darmadi, 2011).

Indonesia's tuna export over the last 25 years has a positive average growth with an average growth rate of export volume is 6.03 percent and the growth rate of export-value is 11.79 percent. The largest tuna markets in the world today are Japan, United States (USA) and European Union (EU) (Koestranti, 1993). Tuna exports to Japan accounted for 27 percent, and to the United States is 17 percent; while exports to the EU amounted to 12 percent (FAO, 2006; 2012). Export of fresh fish and processed products in 2008 reached 2.47 billion US dollars and ranked 10th in terms of its contribution to GDP. In 2009 the export value of fresh fish and its processed products decreased to 2.25 billion US dollars and ranked 11th. Tuna is exported in fresh, frozen and processed forms. The main target of Indonesian tuna export is Japan and US. Export of fresh and frozen tuna to Japan in 2010 amounted to 32.45 percent (KKP, 2011).

Opportunities to increase the export volume of tuna are still very open. Some of the supporting factors to these opportunities are followed. First, the demand for tuna tends to increase every year (Goenarsyah, 1990; BPEN, 1998). This can be seen from the growing volume of Indonesian tuna exports in the period 2006-2011. The increase of human 
awareness on the fishery products as a healthy food and high nutritional value, low cholesterol, and omega-3 fatty acids, encouraging the interest of consumers, especially foreign consumers of tuna. Tuna has all of these advantages. Secondly, Indonesia is a country with great potential as a producer of tuna. The position of Indonesian sea located between the Indian Ocean and the Pacific Ocean provides advantages, because this position is a tuna crossing areas. The sustainable potential of tuna and skipjack is estimated to reach 886,600 tons / year or about 20 percent of the total potential of tuna and skipjack of the world (FAO, 2012). Thirdly, Indonesia has tuna with various species that have high economics value (DKP, 2005; KKP, 2011). Efforts to increase tuna exports should be supported by an increase in the quantity, quality, and value added of tuna, so it needs an integrated effort so that tuna export business can continue to grow in the face of existing challenges (Yuniarta et al., 2017). The role of government and related business actors should be more optimized (Purnomo and Suryawati, 2007; Yeeting et al., 2016).

Efforts to utilize fisheries resources optimally throughout the Indonesian regions are directed to increase foreign exchange and improve the welfare of fishermen and fish farmers. This can be done by expanding the business in the upstream sector related to the downstream business (agro-industry). These efforts are closely linked to governmental policies to integrate the linkages of upstream sectors (industry of input production), fishing business, downstream (agro-industry), to the tuna exporters (Sumaila, Dyck and Baske, 2014). Therefore, the internal problems of fishermen such as education, experience, technology and venture capital; and international-oriented of marketing should be prioritized (Havice and Reed, 2012). On the other hand, the process of capital accumulation, the development of tuna fishery agroindustry, the state of infrastructure, and the regulation to preserve the fishery resources are the key to success (Christian, Labaro and Telleng, 2012).

Based on the things described above, the government's policy is needed to encourage tuna fishery subsector to become a source of national economic growth. Specifically, the policies deemed relevant are increased non-oil exports, increased fishermen's income, expansion of employment opportunities, and increased GDP of the fisheries sector. The export value of fresh tuna can still be improved by increasing the productivity of Indonesian tuna, especially fresh tuna. To increase the export value of Indonesian fresh tuna in the international market, it is necessary political will of government to support tuna industrialization that can improve tuna competitiveness in international market (Djima, 2000; Tolentino-Zondervan et al., 2016).

To answer the above problems, it is necessary to research about the economic model of Indonesian tuna fishery; analysis of policy simulations in the era of trade liberalization. With these economic models, it is expected to formulate appropriate policies to foster fisheries subsector, especially in the case of: (1) providing food, (2) generating foreign exchange, (3) providing employment, (4) a potential market for capital and advanced technology, and (5) as an equalization agent of Indonesia's economic development.

Purposes of this study are to analyze the development of Indonesia fresh tuna exports in the international market during 2000-2016, and to know the factors that affect Indonesia's fresh tuna exports in the international market.

\section{METHODS OF RESEARCH}

This research applies a quantitative approach that discusses the relationship between variables. This study was conducted in the period 2000-2016 to analyse factors that may affect the export of fresh tuna in the international market in that period. The data used is the annual time series data. Data analysis model used in this research is econometric model of simultaneous equation system. This econometric model is a special pattern of the algebraic model, a stochastic element that includes one or more variables (Intriligator, 1978). The data analysis in this study includes the following steps.

Model Specification. Model specifications in this study using the system of simultaneous equations as follows: 
Domestic demand of the fresh tuna:

$\mathrm{DQTS}=e 10+e 21 *$ PITS $+e 22 *$ PDIL $+e 23 *$ GNPriil $+e 14 *$ POP $+e 15 *$ TREN

Domestic price of the fresh tuna:

PITS $=f 10+d 11 * E+f 12 * P X T S W+f 13 * D Q T S+f 14 * Q T T+f 15 * P O P+f 16 * G D P$

Export of the fresh tuna to Japan:

VXTSJ $=g 10+g 11 *$ PXTSIKJ $+g 12 * E+g 13 * G D P J+g 14 *$ POPJ $+g 15 * Q T T$

Export of the fresh tuna to USA:

VXTSUS $=h 10+h 11 *$ PXTSIKUS $+h 12 * E+h 13 * G D P U S+h 14 * P O P J+h 15 * Q T T$

Where:

DQTS: Fresh Tuna domestic demand;

PITS: Fresh Tuna domestic price;

PDIL: Domestic price of other fishes;

GNPRiil: Income of any countries;

QTT: Production of Tuna;

POP: Population;

VXTSJ: Fresh tuna export to Japan;

PXTSIKJ: Price of the fresh tuna exported to Japan;

PXTSIKUS: Price of the fresh tuna exported to USA;

GDPJ: National income of Japan;

PXTSTH: Price of the fresh tuna exported to Thailand;

VXTSUS: Export of fresh tuna to USA;

PXTSIKSI: Price of the fresh tuna exported to Singapura;

GDPUS: National income of USA;

QTT: Production of Tuna.

Model Validation. Prior to use in the simulation analysis, a predictive power test of the model was performed. In this research, validation is done by using comparison of actual value and prediction value (Root Mean Square Percentage Error - RMSPE- and U-Theil). The model's ability to predict the better, if the RMSPE and U-Theil values are getting smaller. RMSPE values below 30 percent and U-Theil below 0.2 are expected values (Theil and Zellner, 1962; Pindyck and Rubinfeld, 1991).

Simulation Procedure. In this study a policy simulation analysis was conducted to see the impact of policy changes on the economic performance of fresh tuna trade. To answer the research objectives, then simulation for the period 2000-2016. Before the forecasting simulation is done, firstly forecasting all exogenous variables, using time series data.

\section{RESULTS AND DISCUSSION}

Results of Estimation. Once the model parameters are repeatedly estimated, the results are obtained that all explanatory variables in the behavioral equation have values that correspond to expectations (economic criteria) and are statistically feasible. Three of the six equations used have the coefficient of determination (R2) greater than $80 \%$. In general, the explanatory variables included in the behavioral equations in this study are able to explain well the performance of each endogenous variable. While in testing the parameters based on the t-test has been attempted to obtain the best results (the lowest error), after the economic criteria are met; in this study the level of significance used is tolerant to 0.20 . This research describes the economic behavior related to fresh tuna fishery sub-sector, namely: (1) Domestic demand for fresh tuna is influenced by the domestic proce of fresh tuna, other tuna prices, national income and population; (2) Output price is influenced and suggest a negative relation with production level, otherwise it is positively related to consumption, export price and rupiah exchange rate; (3) Export prices, domestic prices and rupiah exchange rate, have a significant effect on national fresh tuna export. The behavior of the 
tuna fishing sector like this is in line with the results of research conducted by previous fisheries researchers (ITPC, 1991; FAO/GLOBEFISH, 2006; Pianet, Nordstrom and Dewals, 2009; Langley et al., 2004; Hidaka and Torii, 2005; Allen, 2010; Pons, Melnychuk and Hilborn, 2018).

Estimation of Export Model of the Fresh Tuna in International Market. The estimation of factors affecting export of fresh tuna in the international market in 2000-2016 is influenced by the following variables (Tables 1-4).

Table 1 - Results of Parameter Estimation of the Fresh Tuna Demand Equation

\begin{tabular}{|c|c|c|c|c|}
\hline \multicolumn{5}{|c|}{ Estimation of fresh tuna demand } \\
\hline Variabel & Parameter Estimation & Standar Error & T Value & p-value \\
\hline Intercept & 67943910 & 41451095 & 1,64 & 0,1322 \\
\hline PITS & 3,883695 & 1,897812 & $-2,05$ & 0,0679 \\
\hline PDIL & 31,2848 & 30,94973 & 1,01 & 0,3359 \\
\hline GNPRiil & 0,028628 & 0,023878 & 1,20 & 0,0582 \\
\hline POP & $-0,32501$ & 0,198400 & $-1,64$ & 0,1324 \\
\hline TREN & 959781,6 & 571670,2 & 1,68 & 0,1241 \\
\hline $\begin{array}{l}\mathrm{R}^{2}=0,84173 \\
\text { F }=10,64\end{array}$ & \multicolumn{4}{|l}{} \\
\hline
\end{tabular}

Source: Data analysis, 2018.

Table 2 - Results of Parameter Estimation of the Fresh Tuna Domestic Price Equation

\begin{tabular}{|c|c|c|c|c|}
\hline \multicolumn{5}{|c|}{ Domestic price of fresh tuna } \\
\hline Variable & Parameter Estimation & Standar Error & T Value & p-value \\
\hline Intercept & $-5970,65$ & 9168,347 & $-0,65$ & 0,5283 \\
\hline E & 1,725429 & 1,183992 & 1,46 & 0,1230 \\
\hline PXTSW & 0,280059 & 0,164540 & 1,70 & 0,1168 \\
\hline DQTS & 0,023555 & 0,042367 & 0,56 & 0,1194 \\
\hline QTT & $-0,02533$ & 0,016725 & $-1,51$ & 0,1581 \\
\hline R2 $=0,64742$ & \multicolumn{4}{c}{} \\
F =51,674 & \multicolumn{5}{l}{} \\
\hline
\end{tabular}

Source: Data analysis. 2018.

Table 3 - Results of Parameter Estimation of the Fresh Tuna Demand in the Japan market

\begin{tabular}{|c|c|c|c|c|}
\hline \multicolumn{5}{|c|}{ Export Demand of fresh tuna to Japan } \\
\hline Variabel & Parameter Estimation & Standar Error & T Value & p-value \\
\hline Intercep & 21558815 & 4045368 & 5,33 & 0,0003 \\
\hline PXTSIKJ & $-27,0867$ & 62,26923 & $-0,43$ & 0,0728 \\
\hline E & 6,221759 & 16,12868 & 0,39 & 0,1078 \\
\hline GDPJ & $-234,423$ & 190,6259 & $-1,23$ & 0,2470 \\
\hline POPJ & 71,06974 & 55,18982 & 1,29 & 0,1268 \\
\hline TRJ & $-0,88453$ & 12,69847 & $-0,78$ & 0,0544 \\
\hline R2 $=0,75940$ & \multicolumn{4}{l}{} \\
F =56,31
\end{tabular}

Source: Data Analysis, 2018.

Table 4 - Results of Parameter Estimation of the Fresh Tuna Demand in the USA market

\begin{tabular}{|c|c|c|c|c|}
\hline \multicolumn{5}{|c|}{ Export Demand of fresh tuna to USA } \\
\hline Variable & Parameter Estimation & Standar Error & T Value & $p$-value \\
\hline Intercept & 911524,3 & 401826,8 & 2,27 & 0,0467 \\
\hline PXTSIKUS & $-9,49151$ & 2,618052 & $-3,63$ & 0,0046 \\
\hline $\mathrm{E}$ & 9,291016 & 8,694664 & 1,07 & 0,3104 \\
\hline GDPUS & $-4,60528$ & 6,481488 & $-0,71$ & 0,4936 \\
\hline POPUSA & 5,84455 & 5,147232 & 1,14 & 0,2827 \\
\hline TRUS & $-4985,73$ & 4,940 & $-6,44$ & 0,4593 \\
\hline QTT & 9,9983 & 3,985 & 3,8774 & 0,0076 \\
\hline $\begin{array}{l}\text { R2 = 0,76461 } \\
F=75,50\end{array}$ & & & & \\
\hline
\end{tabular}

Source: Data analysis, 2018. 
Based on the results of data analysis (Tables 1-4), it can be seen the factors that affect the export of fresh tuna as follows.

Domestic Demand for Fresh Tuna. Results indicate that domestic price of fresh tuna negatively affects domestic demand for fresh tuna. If the price of fresh tuna rises, it will decrease domestic demand, if the price of other fishes rises has a positive effect on the domestic demand for fresh tuna. The pattern of consumption of Indonesian society is still dependent on the price of food commodities. National income (real GNP) and population are parameters that positively affect domestic demand for fresh tuna and the increase in population will also increase consumption and increase domestic demand for fresh tuna. Based on the results of data analysis (Table 1 to 4 ), it can be seen the factors that affect the export of fresh tuna as follows.

Domestic demand for Fresh Tuna. The result shows that the price of fresh domestic tuna has negatively effect on domestic fresh tuna demand. If the price of fresh tuna is domestic, it will decrease domestic demand, on the other hand if the price of other fish has a positive effect on the demand of fresh domestic tuna. The pattern of consumption of Indonesian society is still dependent on the price of food commodities. National income (real GNP) and population are parameters that positively affect domestic demand for fresh tuna, and the increase in population will also increase consumption and increase demand for domestic tuna.

Domestic price of the fresh tuna. Results showed that fresh tuna production had a negative effect on fresh tuna price in the domestic market of -1.51. If fresh tuna production rises, it will reduce the price of tuna in the domestic market. The price of fresh tuna in the international market positively affects the domestic price of tuna. Domestic prices of tuna will rise if the price of tuna in the international market increases, and the domestic proce of tuna will decrease if the price of tuna in the international market decreases. Domestic demand of tuna positively affects the domestic proce of tuna. As domestic demand increases, it will increase the price of tuna according to the law of demand which says that prices will increase as demand increases. On the contrary decline in domestic demand will reduce the price of tuna (Stanislaus, 1985). All results of this analysis apply with the assumption that other factors meet the assumption of ceteris paribus.

Export demand of Indonesian fresh tuna to the Japanese market. Results of analysis show that the price of Indonesian tuna in Japanese market negatively affects the demand of Indonesian tuna in Japan. The price of Salmon fish is positively related to the demand for Indonesian tuna. Japan's domestic income has a positive effect on demand for Indonesian tuna in the Japanese market.

The demand for domestic tuna has a positive effect on the domestic price of tuna. As domestic demand increases, it will increase domestic prices, according to the law of demand in which the prices will increase following the demand increases. On the contrary the decline in domestic demand will reduce domestic prices of tuna.

Export demand of Indonesian fresh tuna to the US Market

The result of parameter estimation shows that Indonesian tuna price in USA has negative effect to export demand of tuna in USA of -3.63 . The increase in tuna prices will reduce the demand for tuna exports in USA. The price of salmon (as a substitute of tuna) in USA positively related (1.07) to the demand for Indonesian tuna. The increase in salmon prices will raise demand for Indonesian tuna; consumers in the USA will choose tuna instead of salmon.

Simulation of the export policy of fresh tuna to the international market. To see the impacts of current policy changes and current phenomena on the endogenous variables in the simultaneous equation system, several simulations of exogenous variables are made. Changes in these variables can have a positive impact, negative impact, or no impact on the endogen variables at all.

Impacts of the policy to increase export of Indonesian fresh tuna in the international market in 2000-2016 can be seen in Table 2. Based on indicators of fresh tuna export performance, policy scenarios that can improve performance of Indonesian fresh tuna exports are: (1). Increase in the number of tuna fishing boats by $25 \%$, (2) Depreciation of the 
rupiah at $30 \%$, (3) Decrease in the domestic price of tuna by $10 \%$, (4) Decrease in interest rate of $2.5 \%$, (5) Removal of import tariff, (6) Implementation of appropriate technology of $10 \%$. These are in line with the results of research conducted by other researchers (Ananda, 2002; Angra, 2007; Havice, 2009; Amandè, et al., 2010; Havice, and Campling, 2010; Miyake et al., 2010; Campling, 2012; Bailey et al., 2016).

Table 5 - Impacts of the fresh tuna export policies

\begin{tabular}{|c|c|c|c|c|c|c|c|c|}
\hline \multirow{2}{*}{ No. } & \multirow{2}{*}{ Performance indicator } & \multirow{2}{*}{ Simulation value } & \multicolumn{5}{|c|}{ Impact of change (\%) } \\
\cline { 5 - 9 } & & & SIM 1 & SIM 2 & SIM 3 & SIM 4 & SIM 5 & SIM 6 \\
\hline 1 & Domestic demand for fresh tuna & 389066,9 & 0,88 & 0,09 & 0,25 & 0,07 & 0,78 & 0,28 \\
\hline 2 & Proce of fresh tuna & 25618,72 & 0,36 & 18,39 & 0,20 & 0,41 & 2,50 & 1,62 \\
\hline 3 & Export demand of Japan market & 490641,86 & 5,35 & 0,13 & 0,04 & 0,04 & $-0,62$ & 1,01 \\
\hline 4 & Export demand of USA market & 488243,67 & $-7,79$ & 0,01 & 0,01 & $-0,93$ & $-0,55$ & 0,56 \\
\hline 5 & Export demand of EU market & 290471,54 & $-0,46$ & 0,15 & 0,21 & $-0,311$ & $-0,77$ & 1,65 \\
\hline 6 & Export demand of Singapore market & 199641,18 & $-22,45$ & 0,26 & 0,56 & $-0,12$ & $-0,55$ & 1,26 \\
\hline
\end{tabular}

Source: Data analysis, 2018.

Notes:

SIM1 = Increase of tuna fishing boats by $25 \%$;

SIM2= Depreciation of rupiah exchange rate by $30 \%$;

SIM3 $=$ Decrease of tuna price by $10 \%$;

SIM4 = Decrease of interest rate by $2,5 \%$;

SIM5= Removal of import tariff;

SIM6 = Implementation of appropriate technology by $10 \%$.

Government policies to encourage increased tuna fishing yields are simulated with an increase in the number of fishing boats $(10 \%)$ provided by the government and channeled through fishermen cooperatives. The simulation is considered to be relevant enough to reflect the government's efforts to encourage progress of tuna fishing business, so it can be seen how it impacts on Indonesian fresh tuna exports in the international market. Increase in the number of tuna fishing boats by 1000 units or $25 \%$ of the average number of boats can increase fish production by $3 \%$. However, this increase in tuna production caused a decrease in domestic proce of tuna by $0.36 \%$, and this price reduction will increase tuna demand by 1.02. It is in line with the results of research conducted by other researchers (Floyd and Pauly, 1984; Fonteneau et al., 2000; Lennert-Cody, Roberts and Stephenson, 2008; Amandè et al., 2017.).

Depreciation policy of the rupiah against US $\$$ is very favorable for the fresh tuna trade. Because it can encourage the increase of fresh tuna exports. The rupiah depreciation of $25 \%$ can increase the export of fresh tuna, thus having a role in increasing national income. The production of fresh tuna fishery needs to be improved to meet domestic consumption. Depreciation of the rupiah exchange rate against the US dollar is expected to increase national income. The $2.5 \%$ reduction in the interest rate has not been able to improve performance of fishery sub sector. This indicates that the prevailing interest rate is still high for fishery business, so the interest rate decline has not been able to encourage investors to invest their capital in fisheries, especially tuna fisheries. It is in line with the results of research conducted by other researchers (Anderson, 1977; Kumar, 1997; Havice, 2013; Kuldilok, Dawson and Lingard, 2013).

Decline of the price of Indonesian tuna in the USA market by $10 \%$ has an effect on domestic price decline $(0.43 \%)$; this domestic price always follows the price dynamics of tuna in international market. The fall in domestic prices led to a decrease in tuna production by $5.35 \%$; this occurs because of negative expectations of the actors of tuna fishing effort against declining in fish prices in market.

Tariff removal (simulated) applied by Japan and USA can increase the demand for Indonesian tuna export in Japan by $14 \%$, this amount is considered very important for the development of Indonesian tuna exports. Increased demand for exports in Japan, it is considered that there is a decrease in export demand in the USA by $0.55 \%$; and in aggregates the Indonesian tuna exports increased by $15.87 \%$. This increase in exports gives positive expectation for the fresh tuna fishing business, so it can be simulated to increase 
fresh tuna production by $13.99 \%$. This is in line with the results of research conducted by other researchers (Sunorita and Tjarsono, 2014; Widya, 2015; Digal, Placencia and Balgos, 2017).

\section{CONCLUSION}

Factors affecting domestic demand for fresh tuna are national income and population. The price of domestic tuna affects the demand for domestic fresh tuna negatively (non significant). The price of shrimp affects the demand of domestic tuna positively (non significant).

The analysis of factors affecting the demand for Indonesian fresh tuna exports in international markets is attributed to the demand characteristics of the largest importing countries, namely the United States and Japan. Factors that significantly influence the price of Indonesian tuna in the country, the price of salmon, the price of Thai tuna, the exchange rate of the rupiah against the currency of the importing country, the importing country GNP, the number of people and the tariff applied to the Indonesian tuna.

\section{REFERENCES}

1. Allen, R., 2010. 'International Management of Tuna Fisheries: Arrangements, Challenges and a Way Forward'. FAO Fisheries and Aquaculture Technical Paper, No. 536. Rome: FAO.

2. Amandè, M.J., J.Ariz, E.Chassot, A.Delgado, D.Gaertner, H.Murua, R.Pianet, J.Ruiz and P.Chavance. 2010. Bycatch of the European purse seine tuna fishery in the Atlantic Ocean for the 2003 - 2007 periods. Aquatic Living Resources, 23, pp.353-362.

3. Amandè, M.J., P.Dewals and J.N'Cho Amalatchy. 2017. Retaining by-catch to avoid wastage of fishery resources: How important is by-catch landed by purse seiners in Abidjan? Collect. Vol. Sci. Pap. ICCAT, 73(3): 947-952.

4. Ananda, C. 2002. The Supply Analysis of Indonesian Shrimp on The International Market, Fakultas Ekonomi Universitas Brawijaya, Malang.

5. Anderson, L.G. 1977. The Economic of Fisheries Management. The Johns Hopkin University Press. Baltimore and London.

6. Angra, I.B. 2007, Analisis Faktor-faktor yang Mempengaruhi Permintaan Ekspor Tuna Segar Indonesia. Skripsi, undergraduate research.

7. Bailey, M., A.M.M. Miller, S.R.Bush, P.A.M. van Zwieten and B. Wiryawan. 2016. Closing the Incentive Gap: The Role of Public and Private Actors in Governing Indonesia's Tuna Fisheries. Journal of Environmental Policy \& Planning, 18(2): 141-160.

8. BPEN. 1998. Identifikasi Peluang Pasar Ikan Tuna Indonesia. Departemen Perdagangan. Jakarta.

9. Campling, L. 2012. The Tuna 'Commodity Frontier': Business Strategies and Environment in the Industrial Tuna Fisheries of the Western Indian Ocean. Journal of Agrarian Change, 12( 2 and 3): 252-278.

10. Christian J., L.L.Labaro dan A.T.R. Telleng. 2012. Kajian Musim Penangkapan Ikan Tuna dengan Alat Tangkap Handline di Laut Maluku. Jurnal IImu dan Teknologi Perikanan Tangkap, 1(1): 6-9.

11. Darmadi. 2011. Eksplorasi Ikan Tuna. http:// www.dhamadharma.wordpress.com/

12. Digal, L.N., S.G.P. Placencia and C.Q. Balgos. 2017. Market assessment on the incentives and disincentives for the adoption of sustainable practices along the tuna value chain in Region 12, Philippines. Marine Policy, 86: 39-46

13. Djima, H. 2000. Kajian Peluang Ekspor ke Cina Kasus Ikan Tuna, UniversitasIndonesia, Jakarta.

14. FAO, 2012. Fisheries Statistic. Food and Agriculture Organization of the United Nation. Rome.

15. FAO/GLOBEFISH. 2006. Review of Global Tuna Trade and Major Markets, Food and Agriculture Organization/GLOBEFISH, Rome. 
16. Floyd, J. and D. Pauly. 1984. Smaller size tuna around the Philippines-can fish aggregating devices be blamed. Infofish Marketing Digest, 5/85: 25-27.

17. Fonteneau, A., J. Ariz, D. Gaertner, V. Nordstrom, and P. Pallares. 2000. Observed changes in the species composition of tuna schools in the Gulf of Guinea between 1981 and 1999, in relation with the Fish Aggregating Device fishery. Aquatic Living Resources 13:253-257.

18. Goenarsyah, I. 1990. Studi Tentang Permintaan dan Penawaran Komoditi Ekspor Pertanian (Udang). Biro Perencanaan Departemen Pertanian bekerja sama dengan IPB Bogor.

19. Havice, E. and K. Reed. 2012. Fishing for Development?Tuna Resource Access and Industrial Change in Papua New Guinea. Journal of Agrarian Change, 12 (2-3): 413-35.

20. Havice, E. 2009. Shifting Tides: The Political Economy of Tuna Extraction in the Western and Central Pacific Ocean. Doctoral dissertation, University of California - Berkeley.

21. Havice, E. 2013. Rights-based management in the Western and Central Pacific Ocean tuna fishery: Economic and environmental change under the Vessel Day Scheme. Marine Policy, 42: 259-267

22. Havice, E. and L.Campling. 2010. Shifting Tides in the Western Central Pacific Ocean Tuna Fishery: The Political Economy of Regulation and Industry Responses'. Global Environmental Politics, 9 (1): 89-114.

23. Hidaka, T. and T.Torii. 2005. Evaluation of status and competitive advantage of tuna aquaculture in Australia. Journal of Rural Problems, Vol. 41, pp. 309-16.

24. ITPC. 1991. Indonesia and the Changing Market. Profile Produk Ikan Beku di Jepang. Pusat Promosi Perdagangan Indonesia, Departemen Perdagangan, Tokyo. Kementrian Kelautan dan Perikanan. Kelautan dan Perikanan dalam Angka 2009, Jakarta

25. KKP. 2010. Rencana Strategis Kementerian Kelautan dan Perikanan Tahun 2009-2014.

26. KKP. 2011. Kelautan dan Perikanan dalam Angka. Kementerian Kelautan dan Perikanan

27. Koestranti, R. 1993. Kajian Impor Pasar Jepang Terhadap Tuna (Thunnus sp) Indonesia. Skripsi. Fakultas Perikanan Institut Pertanian Bogor, Bogor.

28. Kuldilok, K.S., P.J. Dawson and J.Lingard. 2013. The export competitiveness of the tuna industry in Thailand. British Food Journal, 115(3): 328-341.

29. Kumar, S. 1997. Optimal Economic Fishery Effort in the Maidivian Tuna Fishery: An Appropriate Model. University of Newcastle New South Wales, Australia.

30. Kusumastanto, T. 2008. Kebijakan dan Strategi Peningkatan Daya Saing Produk Perikanan Indonesia, Pusat Kajian Sumberdaya Pesisir dan Kelautan, IPB.

31. Langley, A., A.Wright, G.Hurry, J.Hampton, T.Aqorua and L.Rodwell. 2009. Slow steps towards management of the world's largest tuna fishery. Marine Policy, 33(2): 271-279.

32. Lennert-Cody, C. E., J. J. Roberts, and R. J. Stephenson. 2008. Effects of gear characteristics on the presence of bigeye tuna (Thunnus obesus) in the catches of the purse-seine fishery of the eastern Pacific Ocean. Ices J. of Mar. Sci. 65:970-978.

33. Miyake, M.P., P.Guillotreau, ; C.H.Sun, G.Ishimura. 2010. Recent developments in the tuna industry: Stocks, fisheries, management, processing, trade and markets. FAO Fisheries and Aquaculture Technical Paper; Rome Iss. 543: 115-125.

34. Onolawe, F. and Fitri. 2011. Analisis Potensi Lestari Sumberdaya Perikanan Tuna Long Line di Kabupaten Cilacap, Jawa Tengah. Maspari Journal, 03: 24-29.

35. Parris, H. 2010. Tuna dreams and tuna realities: Defining the term "maximising economic returns from the tuna fisheries" in six Pacific Island states. Marine Policy, 34(1): 105-113.

36. Pianet, R., V.Nordstrom and P.Dewals. 2009. French Purse-Seine Tuna Fisheries Statistics in the Indian Ocean, 1981-2008. IOTC-2009-WPTT-23. Victoria: IOTC.

37. Pons, M., M. C.Melnychuk and R.Hilborn. 2018. Management effectiveness of large pelagic fisheries in the high seas. Fish and Fisheries, 19(2): 260-270.

38. Reid, C., D.Squires, Y.Jeon, L.Rodwell and R.Clarke. 2003. An Analysis of Fishing Capacity in the Western and Central Pacific Ocean Tuna Fishery and Management Implications. Marine Policy, 27 (6): 449-69. 
39. Spare, P. and S.C.Venema. 1999. Introduksi Pengkajian Stock Ikan Tropis, Buku I Manual, Edisi Bahasa Indonesia. Jakarta: Pusat Penelitian dan Pengembangan Perikanan.

40. Stanislaus, S.M. 1985. Farmer's Respon to Price Changes in a Developing Economy. Ashish Publishing House. New Delhi.

41. Sularso, A. 2009. Overfishing, Over-capacity, and Illegal Fishing: Case Study of Arafura sea. Research and Development Institute of the Fishery and Marine Ministry, Indonesia. Jakarta.

42. Sumaila, U.R., A.Dyck and A.Baske. 2014. Subsidies to tuna fisheries in the Western Central Pacific Ocean. Marine Policy, 43: 288-294

43. Sunoko, R. and H.-W.Huang. 2014. Indonesia tuna fisheries development and future strategy. Marine Policy, 43: 174-183.

44. Sunorita, M. and I.Tjarsono. 2014. Kebijakan Hambatan Non Tarif di Pasar Uni Eropa terhadap Ekspor Komoditas Udang Indonesia. Jurnla Transional, 6(1): Xx.

45. Tolentino-Zondervan F., P.Berentsen, S.Bush, J.Idemne, R.Babaran and A.O. Lansink. 2016. Comparison of Private Incentive Mechanisms for Improving Sustainability of Filipino Tuna Fisheries. World Development, Volume 83, 2016.

46. Widya, O. 2015. Analisis Dampak Non Tariff Measures (NTMs) Terhadap Ekspor Ikan Tuna Indonesia ke Negara Tujuan Utama [Tesis]. Institut Pertanian Bogor.

47. Yeeting, A.D., S.R.Bush, V.Ram-Bidesi and M.Bailey. 2016. Implications of new economic policy instruments for tuna management in the Western and Central Pacific. Marine Policy, 63: 45-52.

48. Yuniarta, S., P.A.M. van Zwieten, R.A.Groeneveld, S.H.Wisudo, E.C van lerland. 2017. Uncertainty in catch and effort data of small- and medium-scale tuna fisheries in Indonesia: Sources, operational causes and magnitude. Fisheries Research, 193: 173183. 